BARBARA KOŻUSZNIK

MAŁGORZATA CHRUPAŁA-

PNIAK

MONIKA SULIMOWSKAFORMOWICZ

\title{
Team dimension \\ of relational competence of organisation - psychological perspective*
}

Prof. Barbara Kożusznik University of Silesia in Katowice

Małgorzata Chrupała-Pniak, Ph.D. University of Silesia in Katowice

Monika Sulimowska-Formowicz, Ph.D.

University of Silesia in Katowice

\section{Introduction}

It has been over 30 years since managers were searching for new characteristics of organisational competencies determining the competitive advantage on the market (Prahalad, Hamel 1990; pp. 79-91, Stalk, Evans, Schulman 1992, pp. 57-69, Allred, Fawcett, Wallin, Magnan 2011, pp. 130-131). The contemporary knowledge-based global economy poses specific requirements for organisations in respect of dynamic and unique competencies and skills (Blomqvist, Levy 2006, pp. 32, Krzakiewicz, Cyfert, 2014, p. 9). In their reflections on relational approach Dyer and Singh (1998, pp. 660-679) emphasise that a part of organisational resources essential to gain the competitive advantage is located in non-traditional sources, e.g. in interorganisational competencies and routines.

*This article is an outcome of the project entitled: 'Relational competence as a determinant of effectiveness and efficiency of inter-organizational relations. The project benefited financial support from the Polish National Centre of Science (Narodowe Centrum Nauki) - Decision no. DEC2012/05/B/HS4/03635 (project leader - Monika Sulimowska-Formowicz). 
As a part of this research trend there has been observed an increasing interest in issues of corporate relations with other organisations on the market. According to researchers, these relations may result in building up new knowledge and developing skills and, with time, they may be considered as a key factor for a company's success on the market (Ciszewska-Mlinaric, Obłój 2011, pp. 2335; Sulimowska-Formowicz, 2013). Relational competence of the organisation belongs to a group of key success factors and is defined as the organizational capability of a particular firm to cooperate with other actors in the network, enabling access to external knowledge, accelerating its transfer and providing optimal management in achieving organizational objectives (Lorenzoni, Lipparini 1999, pp. 317-338). It is a dynamic capability which reconfigures under the influence of organizational learning and gaining experience by firms (Teece et al. 1997, pp. 509-533). It is also a meta-capability since it refers to both, all organisational resources forming organisational competencies and a sum of a firm's relations with actors in the network, not solely to individual relations between two organisations.

The aim of this paper is to analyse an interdisciplinary nature of relational competence by demonstrating its psychological and social dimension and underlining the significance of psychological factors responsible for functioning of teams engaged in inter-organisational co-operation and contributing to shaping relational competence of the organisation. The most essential assumption taken for our considerations with regard to significance of psychological factors for relational competence of the organisation is its recognition as a dynamic capability of key importance for strategic processes of contemporary organisations (Hodgkinson, Healey 2011, pp. 1500-1516). Intra- and inter-organisational phenomena constituting relational competence are dynamic systems and, as determinants of potentiality of the organisation, manifest themselves at its different levels (individual, team and organisational ones). At the end of the previous century, Chan (1998, pp. 234-246) demonstrated the need to analyse organisational phenomena at an individual, team and general organisational levels.

The main aim of this article refers to liason between relational competence in inter-organisational cooperation and specific psychological characteristics of teams involved in cooperation. We assume that at a level of an individual, and similarly at a team level, there must arise circumstances conducive to effectiveness of relations, such as open and efficient cooperation, willingness to take management responsibility, autonomous motivation and work commitment. Which of these circumstances create the ability to form and maintain relations

Team dimension of relational competence of organisation - psychological perspective 
with other organisations, and which ones are responsible for this to a smaller extent? Do processes and structures, without which we cannot imagine effective relations with other organisations, form themselves at a team level? This poses a question to which we seek answers in our research. Our assumption is that the higher level of such psychological properties, which are linked with an ability to interact, cooperate, exchange information and be flexible, the higher the relational competence of the organisation will be. The novelty of our approach is the perception of relational competence as an outcome of cooperation at different organisational levels and analysing its determinants at all three levels of organisation (Sulimowska-Formowicz 2015).

\section{Inter-organisational cooperation - psychological theoretical foundation}

Contemporary psychology in a modest degree deals with clarification of complex dynamic inter-organisational relations influencing, among others, relational competence. Although there have been some studies regarding a concept of interpersonal trust, attitudes towards cooperation, roles of particular individuals engaged in relations, significance of interpersonal and organisational communication and problem solving, which characterise successful and unsuccessful inter-organisational relations, however, there is no a complex theory laying the foundations for scientific research into psychosocial factors of relational competence. The objective of our research is to contribute to filling this gap and indicating psychological variables having impact on inter-organisational cooperation. Referring to the classic research in social and organisational psychology (Katz, Kahn 1978; Schein 1988), we are presented with different characteristics of organisational behaviour conducive to organisational cooperation, nevertheless, psychologists pay relatively little attention to interorganisational relations (Ring, Van de Ven 1994, pp. 90-118). Thus, within the context of inter-organisational cooperation, leading theories of social psychology focus on issues of intergroup conflicts, while cooperation is treated by default as the opposite behaviour (Deutsch 2005). A separate group of theories employed for the analysis of inter-organisational cooperation constitute management and leadership theories (Bass 1990; Chemers 2001; Grauman, Moscovici 1986). A modern approach to management strongly emphasises complexity of the construct. What appears to be particularly promising in this respect are social cognitive theories which give a new perspective to mechanisms of leadership by indicating its determinant factors inherent to a group itself and its psychological importance for its members. These theories somehow exempt a leader from the

9

BARBARA KOŻUSZNIK

MAŁGORZATA CHRUPAŁA-PNIAK MONIKA SULIMOWSKA-FORMOWICZ 
duty to embody specific features and transfer this "responsibility" to expectations regarding prototyping from the group's perspective (that is a prototype of a manager; a prototype seen as a cognitive pattern). Social cognitive theories underline that it is significant that leaders do not need to exercise power to have influence on others since processes connected with social categorisation and depersonalisation automatically make them "influential" due to prototyping.

In management sciences, when researchers characterise relations between organisations, alongside they invoke a body of classic research as a part of social identification theory (Hogg 2001, 2004, pp. 203-231; Hogg, Abrams 1988, Hogg, McGarty 1990, pp. 10-27; Tajfel 1978; Tajfel, Turner 1979). A function of social categorisation is therefore the reduction of complexity of information received from the outer world and the contribution to more effective functioning in market relations (Abrams, Hogg, 1990, 1999; Ellemers, Spears, Doosje 1999; Turner et al., 1987; Worchel et al. 1998, pp. 389-413). Internal similarities of the category and external differences of the category are underlined, and external groups are perceived as more homogeneous than one's own group, which may result in specific integrating behaviour (Linville, Johnes 1980, pp.689-703).

In the last decade of the previous century, the research studies in the field of social identification were enriched by concepts of social attraction and socialisation processes, leadership and group structure (Hogg, Terry 2001). Organisational identification (Ashforth, Mael 1989, pp. 20-39, 1992, pp. 103123) has appeared in the subject literature as a special manifestation of social identification. More recent research in organisational psychology has developed this approach with concepts of organisational commitment and attachment (Herscovitch, Meyer 2002, pp. 474-487, Meyer, Allen 1991, pp. 64-89).

\section{Conditions for team's cooperation in the context of relational competence}

Our theoretical reflections aim at finding an answer to a question what specific and unspecific characteristics of a team are linked with relational competence of the organisation involved in inter-organisational cooperation (Kożusznik 1995, 1996, 2002). According to B. Kożusznik's idea a team has its subjectivity which is a unique composition of features, analogous to personality traits of an individual. In metaphorical terms, a team is aware of itself, motivated and creates strategies for one's own development. A team with strong subjectivity arises as a result of transformations of a group into an organisational unit demonstrating high effectiveness potential (Likert, 1961) and is characterised by an ability of spontaneous regulation of influences (Lewin, 1951), which enables 
efficient achievements of goals and assignments, optimal use of the potential of the whole team as well as its members in work engagement processes. At our times a team is defined as a group of people that are dependent on one another when performing tasks assigned to them, who are collectively responsible for their work outcome, who perceive themselves and are perceived by others as a separate social unit embedded in the framework of the other, bigger social system or systems, creating mutual relations going beyond structural boundaries of the organisation (McCallum, O'Connell 2009, pp. 152-166). An employees' team defined in this manner is an entity being a specific social group, constituting a component of the organisation or a broader structure, and tied by formal and informal "bonds", performing specified task for financial and non-financial gratification (Kożusznik, 2015). A team is an arena for influence interplay covering the balance of forces in a group (dynamics and a group structure), balance of forces in the organisation (task allocation system, exacting task performance, organisational punishments and rewards system), a manager in a managerial role and particular individuals aiming at achieving their goals in work processes.

The assumptions adopted in our research refer to Lewin's force field theory (1951) which presumes that a team engaged in inter-organisational cooperation is an interdependent set of individuals who share responsibility for specific effects of inter-organisational relation and concurrently is characterised by certain features contributing or non-contributing to organisational relational competence. We assume that the conditions for occurrence of organisational relation competence arise at a level of a team (Sulimowska-Formowicz, 2015), and its properties influencing effectiveness may indirectly contribute to relational competence. Therefore, a team finds itself in a special environment of a relation (both intra-organisational and inter-organisational relations) which may be defined as an adequate climate of spontaneous regulations being referred to as a play of influences, oriented at maximal use of all elements of a team in compliance with strategic objectives of the organisation. Analysing a team in respect to its efficiency and functionality, taking into account the significance of cooperation, sharing of management processes and using the potential of the team's diversity to its full, may, in our opinion, considerably enhance the knowledge on psychosocial determinants of relational metacompetence. A dynamic property of teams gives rise to specific 'climate of influence regulation'. Thanks to this climate, factors contributing or noncontributing to effectiveness, are activated or deactivated (in accordance with the force field theory), enabling and facilitating team and inter-organisational

11

BARBARA KOŻUSZNIK

MAŁGORZATA CHRUPAŁA-PNIAK MONIKA SULIMOWSKA-FORMOWICZ 
cooperation, participation and other organisational behaviour as part of interorganisational relations.

We suggest that the analysis of effective potential of a team should be conducted using the concept of H. A. Campion et al. (1993, pp. 823-850). Basing on the achievements of a number of scientific disciplines, including social psychology, a sociotechnical theory, industrial engineering and organisational psychology, the scholars presume that effective teams are characterised by specific properties stemming from five factors: nature of work (self-management, participation, diversity of assignments, meaning of assignments, mission of assignments), mutual dependencies (task dependency, goal dependency, feedback dependency and rewards), composition of a team (heterogeneity, flexibility, size, team working preference), team's functioning context (trainings, managerial support, communication/cooperation between teams), team processes (social support, sharing workload, communication/cooperation within a team). The above properties were confirmed to be significantly and strongly related with productivity and other organizational effectiveness measures, thus, we believe that there is a need to seek psychological sources of relational competence in the structure of team properties.

We have adopted the concept of influence regulation in a team in accordance with B. Kożusznik's deinfluentisation idea - DEI (2002; 2005; 2006). The author defines deinfluentisation as an ability of conscious regulation of one's own influence, lying in conscious weakening, reduction or even its utter deprivation when the influence of other persons or whole groups is more adequate to the requirements of a situation in processes of achieving organisational objectives. The concept of deinfluentisation is based on treating of one's own influence in the organisation as an effectiveness tool, not as an attribute of personal importance and prestige. She perceives a new perspective of analysing influence tactics in the organisation and assumes that it is possible to dispose of non-manipulative power without a loss of a sense of one's own importance, autonomy and a security threat. She presumes that persons characterised by high willingness for deinfluentisation, by getting involved in work processes, consciously assume a role of a 'regulator' of influences which occur in a given group and present behaviour consisting in reducing one's own importance and/or giving space for other influences in a team than one's own. This behaviour is activated in a situation when a person of high DEI, having conducted a rational analysis, claims that the influence in a given situation is due to somebody else (an individual or group) and that their own influence is ineffective or unacceptable, or that the 'repertoire' of available influence tactics has been depleted. Van Knipperberg 
and Steensma (2003, pp. 55-67), as a result of the conducted research, stated that if partners expect to stay in the interaction in the future, they employ less severe influence means and generally try to have less influence on each other. Therefore, we presuppose that persons of high DEI consider a long-term prospect for common and effective functioning, reducing their own influence in a team, whereas in case of assumed short-term relations, more severe influence means may be anticipated. Deinfluentisation means that it is not necessary to change influence tactics from 'cooperation' or 'participation' into 'exerting pressure' or 'coercion', but to stop the influence temporarily or reduce it. This is in accordance with Schein's viewpoint (1988) who maintains that according to situational approach management, most managers are not able to present simultaneously extreme leadership styles depending on a situation. In our model we concurrently assume that deinfluentisation skill may be treated as a regulatory mechanism in relations connected with translocation of influence within a team. We refer to a concept of shared leadership (cf. shared leadership; Wang, Waldman, Zhang 2013, pp. 181-198), the team-level construct and its specific property (Carson, Tesluk, Marrone 2007, pp. 1217-1234) which translates into positive results not only for an individual but also for a team and the whole organisation (Avolio, Jung, Murry, Sivasubramaniam 1996, pp. 173-208; Avolio 2007, pp. 25-33). We suppose that at a team-level there is an exchange of influence among particular individuals in order to focus activities on team and organisational goals achievement. The concept of shared leadership assumes a simultaneous process of transferring and taking over a part or the whole power (see:. empowerment) among team members and sharing of management responsibility among them. Thus, it includes acts of influence exchange at employees' level (lateral dimension), as well as traditional management influence (hierarchical dimension). Classical definitions of shared leadership emphasised processes within the whole team, not exclusively management activities during which dislocation of leadership and management occurs. C. L. Pearce (2003) defines shared leadership as leader behaviours of team members as a whole. Within this meaning of leadership a team as a subject shares and completely participates in managerial tasks (Katzenbach, 1997) crucial for its effectiveness, e.g. motivating each other, sharing of feedback information etc. The research carried out in this area bear out that teams sharing leadership are more efficient (Barry 1991, pp. 3147, Katzenbach, Smith 1993, Manz, Sims 1993, Pearce, Conger, Locke 2003); they manifest to a greater extent the behaviour based on co-operation, co-ordination and innovation (Yeatts, Hyten 1998), and have better understanding of a team's needs related to independence of tasks and co-ordination (Perry et al. 1999, 
pp. 35-52). In our approach we also presuppose that DEI is strongly connected with shared leadership and constitutes its enhancement since it means that in a situation of shared leadership, the influence adequately reaches the 'source' which becomes a 'leader' for a shorter or longer time period.

One of the most thoroughly described psychological factors, identified as supporting inter-organisational co-operation, is collaboration at a level of an individual and teams. It reduces intergroup conflict resulting from functional differences and enhances development and improvement as distinguishing features of relational advantage (Allred, Fawcett, Wallin, Magnum 2011, pp. 129161). What lies at the roots of our model is the assumption that there is general cooperation-orientation of the examined individuals, so-called pro-cooperative approach (we examine the orientation at a level of managers as well of employees, teams and organisations). We start with the premise that the organisations in which managers responsible for building and maintaining inter-organisational relations manifest individual co-operative orientation will promote this approach in their teams, and their organisations will develop mechanisms and procedures catalysing processes of inter-organisational cooperation constituting relational competence.

The subsequent premise is a nature of motivation and work engagement (Schaufeli, Bakker 2010, pp. 10-24). Autonomic motivation and considerable engagement at work may, in our viewpoint, demonstrate identification with the organisation and inter-organisational cooperation, and concurrently facilitate processes of impact regulation and leadership sharing. We perceive motivation according to the self-determination theory developed by R. M. Ryan and E. L. Deci (2000, pp. 68-78).

Within the framework of theoretical conceptions adopted, we believe that the analysed psychological dimensions of relational competence are worth considering in the context of influence regulation in a team. While leadership and management determinants in respect of team effectiveness have their established significance and place in the awareness of researchers and practitioners in organisations, the influence of a group as the whole on its members and a manager, despite a number of documented research studies, has not borne in upon management practitioners in Poland.

\section{Conclusions}

On the basis of the considerations raised in the article, relational competence should be studied at a number of levels and when its definition is formulated and 
model constructed, this multi-level approach should be employed. In accordance with D. Chan's suggestions (1998, pp. 234-246), a multi-layered construct of relational competence is based on the assumption that both, a level of the organisation and a level of the team provide a component indispensable for conceptualisation and operationalisation of relational competence. We search for team-level determinants of relational competence and moderating factors giving rise to them in form of a climate of relations in a team and deinfluentisation. We expect that practical interventions based multilevel research findings will be better grounded by indicating interactions between organisation's levels. We will be able to apply so-called wise interventions (Walton 2014, pp. 73-82) in order to contribute to success and effectiveness of the organisation. The development of precise theories describing and clarifying the reality and the manner in which psychological processes contribute to functioning of the organisation, creates opportunities for close collaboration with management practitioners who will apply our recommendations confirmed by thorough studies and research.

\section{Summary}

Team dimension of relational competence in organization psychological perspective

This article is a part of theoretical model for the research project titled "Relational competence as a determinant of effectiveness and efficiency of inter-organizational relations". The authors deliberate upon team-level determinants of relational competence of organizations involved in inter-organizational cooperation in the light of classic and modern psychological theories and concepts. The aim of this article is to present authors' own approach used in research on relational competence of organizations and based on multilevel analysis of influence regulation in teams (individual-, team- and organizational levels) together with motivation and work engagement. We search for correlations between psychological variables and relational competence and relation's results. We assume that on individual- as well as on team-level preexist some features determining relation's success, such as: open and effective collaboration, readiness to take responsibility for management, leadership division, autonomous motivation and work engagement.

Keywords: relational competence, team characteristics, influence regulation 


\section{Streszczenie}

\section{Zespołowy wymiar kompetencji relacyjnej organizacji - ujęcie psychologiczne}

Artykuł jest częścią teoretycznego modelu badawczego w ramach grantu zatytułowanego "Kompetencja relacyjna jako determinanta wydajności i skuteczności relacji międzyorganizacyjnych". Autorki podejmują rozważania na temat zespołowych uwarunkowań kompetencji relacyjnej organizacji zaangażowanej we współpracę międzyorganizacyjną. Przedstawiają krótki rys klasycznych i współczesnych teorii i koncepcji psychologicznych dotyczących cech zespołów sprzyjających efektywniejszej współpracy w wymiarze międzyorganizacyjnym. Głównym celem artykułu jest prezentacja autorskiego podejścia wykorzystanego w badaniach kompetencji relacyjnej opartego na wielopoziomowej analizie regulacji w pływu w zespołach (poziom jednostki, zespołu, organizacji) przy jednoczesnej kontroli motywacji i zaangażowania w pracę oraz zależności zmiennych psychologicznych z kompetencją relacyjną i wynikami relacji. Zakładamy, że na poziomie jednostek, podobnie jak na poziomie zespołowym muszą zaistnieć właściwości sprzyjające efektywności relacji m.in. otwarta i efektywna współpraca, gotowość do przejęcia odpowiedzialności za kierowanie, współdzielenie się kierowaniem oraz motywacja autonomiczna i zaangażowanie w pracę.

\section{Słowa}

kluczowe: $\quad$ kompetencja relacyjna, cechy zespotu, regulacja wptywu

\section{References}

1. Abrams D., Hogg M. A. (red.) (1990), Social identity theory: Constructive and critical advances, Hemel Hempstead, England: Harvester Wheatsheaf.

2. Abrams D., Hogg M. A. (red.) (1999), Social identity and social cognition, England: Blackwell, Oxford.

3. Allred C.R., Fawcett S. E., Wallin, C. Magnan G. (2011), A Dynamic Collaboration Capability as a Source of Competitive Advantage, "Decision Sciences", Vol. 42, No. 1.

4. Ashforth B. E., Mael, F. (1989), Social identity theory and the organization, "Academy of Management Review", Vol.14, No.1.

5. Avolio B.J. (2007), Promoting more integrative strategies for leadership theorybuilding, "The American Psychologist", Vol. 62. 
6. Avolio B., Jung D., Murry B., Sivasubramaniam N. (1996), Building highly developed teams: Focusing on the process and performance. w: M. Beyerlein, D.Johnson, S. Beyerlein (red.), Advances in interdisciplinary studies of work teams, Vol. 3., CT: JAI Press, Greenwich.

7. Barry D. (1991), Managing the bossless team: lessons in distributed leadership, "Organizational Dynamics", Vol. 21. No. 1.

8. Bass B.M. (1990), Bass and Stogdill's handbook of leadership: Theory, research and managerial applications. Free Press, New York.

9. Blomqvist K., Levy J. (2006), Collaboration capability - a focal concept in knowledge creation and collaborative innovation in networks, "International Journal of Management Concepts and Philosophy", Vol. 2, No. 1.

10. Campion M.A., Medsker G.J., Higgs A.C. (1993), Relations between work group characteristics and effectiveness: implications for designing effective work group,. "Personnel Psychology" Vol. 46. No. 4.

11. Carson J.B., Tesluk P.E., Marrone J.A. (2007), Shared leadership in teams: An investigation of antecedent conditions and performance, "Academy of Management Journal", Vol. 50.

12. Chan D. (1998), Functional relations among constructs in the same content domain at different levels of analysis: A typology of composition models, "Journal of Applied Psychology", Vol. 83, No 2.

13. Chemers M.M. (2001). Leadership effectiveness: An integrative review, w: M.A. Hogg, R.S. Tindale (red.) Blackwell handbook of social psychology, Group processes, UK Blackwell, Oxford.

14. Ciszewska-Mlinaric M., Mlinaric F., Obłój K. (2011), Zdolność relacyjna, kompetencje organizacyjne i wyniki finansowe matych iśrednich firm stoweńskich, "Master of Business Administration", No. 4.

15. Dyer J.H., Singh H. (1998), The relational view: Cooperative strategy and sources of inter-organizational competitive advantage, "Academy of Management Review", Vol. 23.

16. Ellemers N., Spears R., Doosje B., (red.) (1999), Social Identity: Context, Commitment, Content, Blackwell, Oxford.

17. Grauman C.F., Moscovici S. (1986), Changing Concepts of Crowd Mind and Behavior, Springer-Verlag, New York.

18. Hamel G., Prahalad C.K. (1990), The Core Competence of the Corporation, w: D. Hahn, B. Taylor (red.) Harvard Business Review, Vol. 68, No. 3.

19. Herscovitch L., Meyer J. P. (2002). Commitment to organizational change: extension of a three-component model, "The Journal of Applied Psychology”, No. 87.

20. Hodgkinson G.P., Healey M.P. (2011), Psychological foundation of dynamic capabilities: reflection and reflection in strategic management, "Strategic Management Journal" Vo. 32.

21. Hogg M., Terry D. (2001), Social Identity in Organizational Contexts, Taylor and Francis, Ann Arbor. 
22. Hogg M.A. (2001), A social identity theory of leadership, "Personality and Social Psychology Review", Vol. 5. No. 3.

23. Hogg M.A., Abrams D. (1988), Social identifications: A social psychology of intergroup relations and group processes, Routledge, London.

24. Hogg M. A., McGarty C. (1990), Self- Categorization and Social Identity, w: D. Abrams, M.A. Hogg (red.) Social Identity Theory: Constructive and Critical Advances, Harvest Wheatshea, London.

25. Hogg M.A. (2004). Social Categorization, Depersonalization, and Group Behavior, w: M. B. Brewer, M. Hewstone (red.) Self and social identity, Blackwell Publishing, Malden.

26. Katz D., Kahn R.L. (1979), Społeczna psychologia organizacji, PWN, Warszawa.

27. Katzenbach J.R. (1997). The myth of the top management team, "Harvard Business Review", Vol.7. No.6.

28. Katzenbach J.R., Smith D.K. (1993), The wisdom of teams. Creating the High Performance Organization, Harvard Business School Press.

29. Kożusznik B. (1995), Work teams and organization: conscious regulation and getting rid of influence, "The Business Research Yearbook", Vol. 2. University Press of America, Inc. Lanham, MD.

30. Kożusznik B. (1996), Podmiotowość zespołu pracowniczego, Wydawnictwo Uniwersytetu Śląskiego, Katowice.

31. Kożusznik B. (2002), Free Space for Human Capital development. Deinfluentization as Conscious Withdrawal of influence and Its Psychological Correlates, "Polish Journal of Applied Psychology", Vol. 2.

32. Kożusznik B. (2005), Wpływ spoteczny w organizacji, PWE, Warszawa.

33. Kożusznik B. (2015), Zachowania człowieka w organizacji, PWE, Warszawa.

34. Kożusznik B. (2006), Deinfluentization and self-monitoring as influence regulation tactics of Polish women and men managers, "Women in Management Review", Vol.21, No. 2.

35. Krzakiewicz K., Cyfert S. (2014), The Strategic Dimension of the Dynamic Capabilities of Enterprise, "Management", Vol.18, No. 2.

36. Lewin K. (1951), Field Theory in Social Science, Harper and Brothers, New York.

37. Likert R. (1961), New Patterns of Management. New York.

38. Linville P.W., Johnes E.E. (1980), Polarized appraisal of outgroup members, "Journal of Personality and Social Psychology", Vol. 38.

39. Lorenzoni G., Lipparini A. (1999), The leveraging of interfirm relationships as a distinctive organizational capability: a longitudinal study, "Strategic Management Journal" Vol. 20

40. Mael F., Ashforth B. E. (1992), Alumni and their alma mater: A partial test of the reformulated model of organizational identification, ,Journal of Organizational Behavior", Vol. 13. 
41. Manz C. C., Sims H. P. Jr. (1993), Business without bosses: How self-managing teams are building high performance companies, Wiley, New York.

42. McCallum S., O'Connell D. (2009), Social Capital and Leadership Development: Building Stronger Leadership through Enhancing Relational Skills, ,Leadership and Organization Development Journal", Vol. 30, No.2.

43. Meyer J. P., Allen N. J. (1991), A three-component conceptualization of organizational commitment, „Human Resource Management Review”, Vol. 1.

44. Pearce C. L., Conger J. A., Locke E. (2003), Shared Leadership : Reframing the Hows and Whys of Leadership, Sage Publications, Thousand Oaks, CA.

45. Perry M. L., Pearce C. L., Sims H. P., Jr. (1999), Empowered selling teams: How shared leadership can contribute to selling team outcomes, "Journal of Personal Selling and Sales Management", Vol. 19.

46. Ring P.S., Van de Ven A.H. (1994), Developmental process of cooperative interorganizational relationships. "Academy of Management Review", Vol. 19, No. 1.

47. Ryan R. M., Deci E. L. (2000), Self-determination theory and the facilitation of intrinsic motivation, social development, and well-being, "The American Psychologist", Vol. 55.

48. Schaufeli W.B., Bakker A. B. (2010), Defining and measuring work engagement: Bringing clarity to the concept, w: A.B. Bakker, M. P. Leiter (red.), Work Engagement: A Handbook of Essential Theory and Research. Psychology Press Taylor and Francis Group, New York.

49. Schein E. (1988), Organizational Psychology, Prentice Hall, New York.

50. Schruijer S.G.L., (2008), The social psychology of inter-organizational relations, w: S. Cropper (red.) The Oxford Handbook of Inter-Organizational Relations, Oxford University Press, Oxford.

51. Stalk G., Evans P., Shulman L.E. (1992), Competing on capabilities: the new rules of corporate strategy, "Harvard Business Review", Vol. 70, No. 2.

52. Sulimowska-Formowicz M. (2013), Relational capabilities as effectiveness fundamentals of inter-firm cooperation, w: J. Foltys, L. Lesakova, M. Uramowa, A. Wziątek-Staśko (red.), Contemporary Challenges Towards Management III, Wydawnictwo Uniwersytetu Śląskiego, Katowice.

53. Sulimowska-Formowicz M. (2015). Relational competence of a firm as a determinant of inter-organizational relations' effectiveness and efficiency a study from Polish market, proceedings of the 31 IMP Conference, Kolding.

54. Tajfel, H. (red.) (1978), Differentiation Between Social Groups: Studies in the Social Psychology of Intergroup Relations, Academic Press, London.

55. Tajfel H., Turner J.C. (1979), An integrative theory of intergroup conflict, w: W.G. Austin, S. Worchel (red.) The social psychology of intergroup relations, CA: Brooks-Cole, Monterey.

56. Teece D.J., Pisano G., Shuen A. (1997), Dynamic capabilities and strategic management, "Strategic Management Journal", Vol. 17, No 7. 
57. Turner J. C., Hogg M. A., Oakes P. J., Reicher S. D., Wetherell M. (1987). Rediscovering the social group: A self-categorization theory, Basil Blackwell, Oxford.

58. Van Knippenberg B., Steensma H. (2003), Future Interaction Expectation and the use of soft and hard influence tactics, "Applied Psychology: An International Review", Vol. 52 , No.1.

59. Walton G.M. (2014), The new science of wise psychological interventions, "Current Directions in Psychological Science", Vol.23, No.1.

60. Wang D., Waldman D. A., Zhang Z. (2013), A Meta-Analysis of Shared Leadership and Team Effectiveness, "Journal of Applied Psychology", Vol. 99, No. 2.

61. Worchel S., Rothgerber, H., Day A., Hart D., Butemeyer J. (1998), Social identity and individual productivity within groups, „British Journal of Social Psychology", Vol. 37.

62. Yeatts D.E., Hyten C. (1998), High-Performing Self-Managed Work Teams: A Comparison of Theory and Practise, CA: Sage, Thousand Oaks, CA.

63. Zander A. (1987), Making Groups Effective. San Francisco-London. 